\title{
Designing a mobile user experience student knowledge management system using Lean UX
}

\author{
Condro Kartiko ${ }^{1, *}$, Hesa Abda Arrasyid ${ }^{2}$, Ariq Cahya Wardhana ${ }^{3}$ \\ 1, 2, 3 Department of Software Engineering, Institut Teknologi Telkom Purwokerto, J1. D. I. Panjaitan No. 128, \\ Purwokerto 53147, Jawa Tengah, Indonesia \\ E-mail: condro.kartiko@ittelkom-pwt.ac.id \\ *Corresponding Author
}

ABSTRACT

ARTICLE INFO

Student Affairs at Telkom Purwokerto Institute of Technology has a lot of information and knowledge that all students need to know. However, this information and knowledge have not been maximally conveyed to students. Student affairs have a scope of work to handle the Student Creativity Program (PKM), Student Organization (Ormawa), scholarships, Student Activity Transcripts (TAK), and lectures. Therefore, one of the efforts to facilitate Student Affairs in conveying various knowledge is a Student Knowledge Management System mobile application. User Experience student KMS mobile application designed for mobile devices that focus on interface design. The development of this application interface uses the Lean UX method. The Lean UX method has four stages: Declare Assumptions, Create an MVP, Run an Experiment, and Feedback and Research. The application design is evaluated using the Enhanced Cognitive Walkthrough (ECW) to produce a prototype of a knowledge management system or Knowledge Management System for IT Telkom Purwokerto student affairs according to the user's wishes. The test results show success in all tasks, so it can be concluded that the application design has achieved a good user experience.
Article history

Received:

17 March 2021

Revised:

14 April 2021

Accepted:

14 April 2021

Keywords

Enhanced Cognitive

Walkthrough

Student Affairs

Lean UX

Knowledge, Prototype

Knowledge Management System

User Experience Web Browser

This is an open-access article under the CC-BY-SA license.

\section{Introduction}

According to the organizational structure contained on the student website of Telkom Institute of Technology Purwokerto, Telkom Institute of Technology Purwokerto or IT Telkom is led by the Rector and assisted by three Vice-Rectors. Responsibility for marketing, student affairs, and career development center (CDC) assisted by Vice-Rector III [ 1]. According to the results of interviews with students, the student section has the scope of work to handle the Student Creativity Program (PKM), Student Organization (Ormawa), scholarships, Transcripts of Student Activities (TAK), and lectures.

Knowledge is created, acquired, and discovered by a person or individual. An organization will not be able to create knowledge if it does not have individuals. That is, individuals have a very important role in forming knowledge of an organization. During an interview with Mr. Novanda as Head of Student Affairs at Telkom Purwokerto IT campus, he revealed that the dissemination of knowledge for students at Telkom Purwokerto IT campus still uses websites, blogs, and social media such as WhatsApp. This is also reinforced by the questionnaire data 
involving students by stating that social media such as Line, Facebook, WhatsApp, and Instagram are the largest source of knowledge to gain knowledge about Telkom Purwokerto IT campus.

The campus supports student organizations to provide opportunities for students to develop themselves in various aspects through positive activities. Student affairs have an essential role in the dissemination of knowledge to students. Good knowledge dissemination management will help students to achieve their goals[3].

To centralize the dissemination of student knowledge, a knowledge management system (KMS) was created. KMS plays an essential role because, with a good management system, knowledge will be maintained and widespread. That way, knowledge can be passed down and accessed by all students anywhere and anytime[4]. To facilitate students in managing knowledge, a student KMS mobile application is created.

Based on the results of questionnaires distributed to IT students Telkom Purwokerto on Sunday, December 8, 2019, obtained as many as 35 respondents that can be seen in Fig. 1.

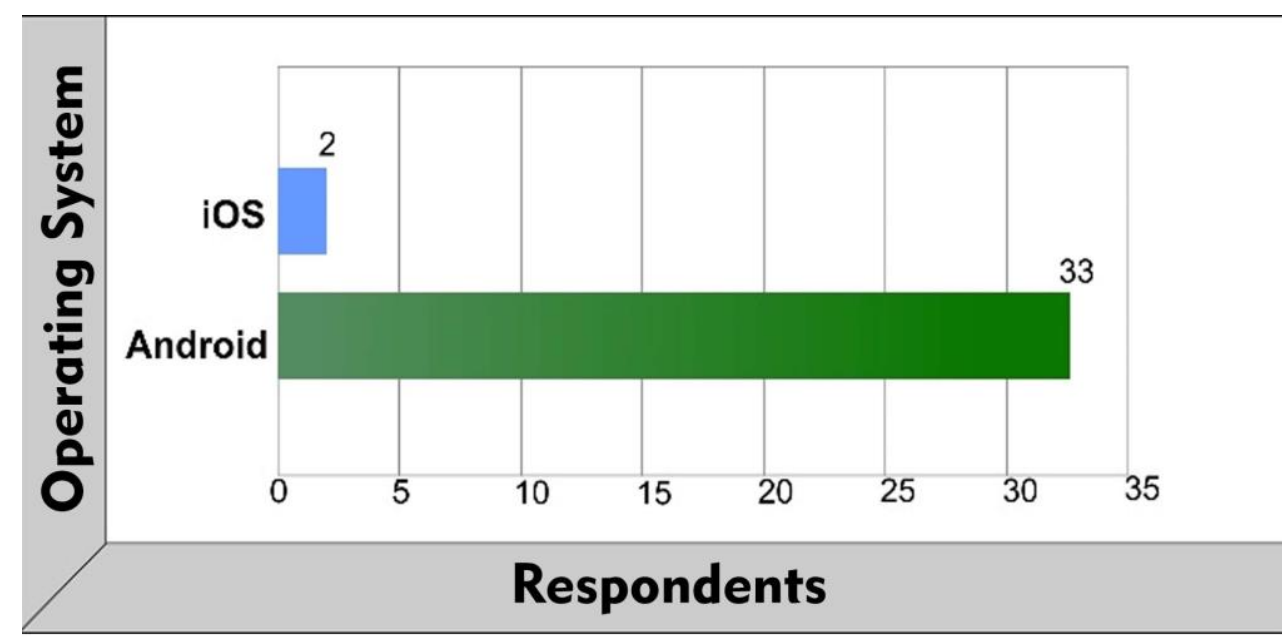

Fig. 1. Graph of the number of mobile operating system users in IT Telkom Purwokerto

Based on Fig.1. it can be seen that the number of smartphone users using the android-based operating system in IT Telkom Purwokerto is more than smartphone users using the iOS-based operating system. Out of 35 respondents, the Android operating system has 33 users, while the iOS operating system has only two users.

The statement is also corroborated by the data disclosed on gs.statcounter.com's website. The website states that smartphone users with Android operating systems in Indonesia are $72.70 \%$, iOS by $26.91 \%$, Windows Phone $0.02 \%$, and the rest using other operating systems. The data was taken in the last 12 months of January 2021.

Research related to KMS, for example, is a hydroponic community website conducted by Ariq Cahya Wardana. The website aims to manage the knowledge of hydroponic cultivation in Bogor city. This system has KMS classification features, namely knowledge capture, knowledge sharing, and knowledge discovery. This website about hydroponic plant cultivation is created using the Knowledge Management Life Cycle method by identifying tacit and explicit knowledge from the hydroponic community. 
Other research related to the lean UX method is the design of a government licensing service website conducted by Dean Apriana Ramadhan and J Arnold Parlindungan Gultom. Interface design is implemented in the form of a high-fidelity prototype in the form of a website. Website features developed are status permissions, change profiles, application permissions, and inbox messaging features. UX is an indicator of the success of a system/application. By using UXdesigned applications can be more effective in achieving the goals of a system/application [8].

\section{Method}

Lean UX has four phase cycles, namely declaring assumptions, creating a Minimum Viable Product (MVP), conducting experiments, and feedback and research. Several Lean UX stages use teamwork mechanisms and create a prototype form of application to see if the designed interface has achieved a good user experience [8]. At the stage of prototype development, the need for user experience (UX) felt by the user should also be considered in addition to functional needs only [9]. Here is an image of the stages of the Lean UX cycle:

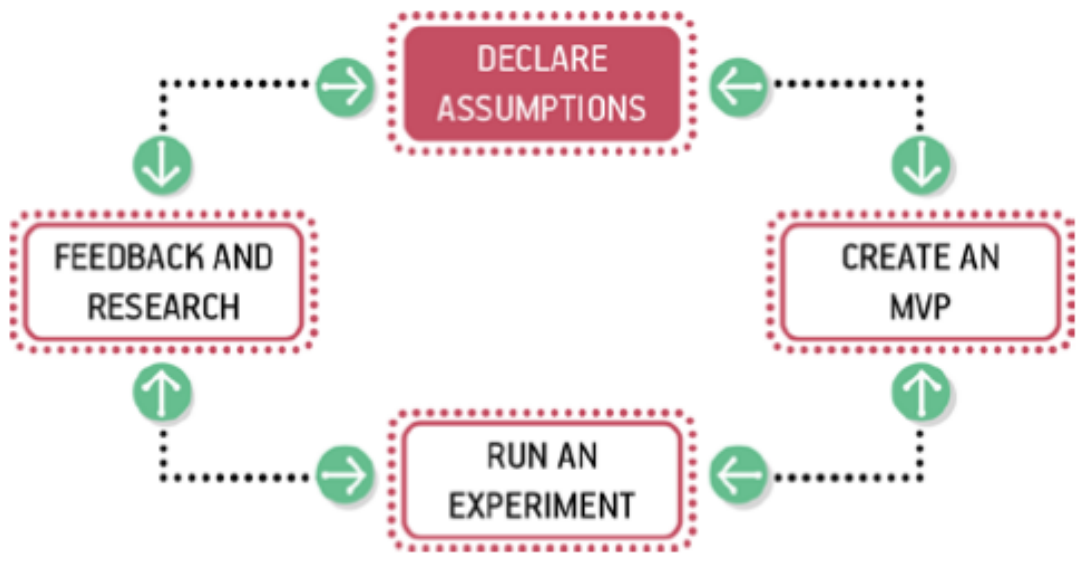

Fig. 2. Lean UX cycle stages [8]

The four stages of Lean UX are used in this stage, namely:

\subsection{Declare Assumptions}

In this first stage, all that is done is to make assumptions. On stating assumptions, there are six stages: problem statements, assumption worksheets, prioritizing assumptions, hypotheses, protopersonas, and collaborative design [8].

\subsection{Create an MVP}

This stage is the prototype stage of the student KMS application. Prototype creation is based on assumptions that have been obtained. The prototype of this student KMS application requires several iterations if at the evaluation stage still needed improvement.

\subsection{Run an Experiment}

The stage of conducting this experiment is included in the MVP creation stage. The developer conducted this experiment. The author, as a developer, will conduct experiments that will then be tested at a later stage. 


\subsection{Feedback and Research}

Feedback and research is the testing phase of an experiment that the developer has conducted. This study's testing team consisted of at least one student and four students as samples from users. The test phase will be evaluated using the Enhanced Cognitive Walkthrough method.

\section{Results and Discussion}

\subsection{Declare Assumptions}

The first stage is the problem statement which results in problems in the research object. The problem statement stage is assumed that the target user is an IT student Telkom Purwokerto who wants to gain knowledge and wants to spread knowledge about student activities. Furthermore, there are two stages of the assumption worksheet, namely user assumptions and business assumptions. On user, assumptions are generated assumptions to solve the problem from the problem statement stage. This application is assumed to be used by students and IT students Telkom Purwokerto. The design of the student knowledge management system serves to facilitate students.

Then on business assumptions produced assumptions to overcome various problems that must be addressed in this system. It is assumed that the five main features are news, group discussion, knowledge sharing, comment on Event, and Bookmark. After these assumptions are made, the next step is to prioritize assumptions. Prioritizing assumptions are made by respondents. Répondants is determined to come from student and IT student Telkom Purwokerto. The minimum respondent is determined using the Slovin formula. Here's the calculation:

$$
\begin{aligned}
& n=\frac{\mathrm{N}}{1+\left(\mathrm{N} \mathrm{x}(\mathrm{e})^{2}\right)} \\
& n=\frac{4178}{1+\left(4178 \times(0,15)^{2}\right)} \\
& n=\frac{4178}{1+(4178 \times 0,0225)} \\
& n=\frac{4178}{1+(94.005)} \\
& n=\frac{4178}{95.005}=43,976
\end{aligned}
$$

The number of active students of IT Telkom Purwokerto is 4178 [10]. By using the potential for leeway using $15 \%$, the minimum respondents after being calculated using the Slovin formula are 44 respondents and, in this study, obtained a total of 62 respondents. The reason for the potential leeway to use $15 \%$ is because there are still many respondents who do not understand what KMS is, so many misfits the purpose of the prioritizing assumption stage.

After the prospective users have assessed from 1 to 10 how important an assumption is, a sorting of assumptions from the highest to the lowest values is performed. Here are the results of sorting assumptions: 


\section{Assumption \#3 get a value of 514}

It is believed that students and students need knowledge-sharing features to share the knowledge owned or download new sciences that want to be learned. This need can be solved by creating a knowledge-sharing feature consisting of several categories of science so that users get the science material according to their needs. The risk in this feature is that students share science materials that are not relevant.

2. Assumption \#1 get a value of 506

It is believed that students and students need information about the campus that is happening or that has happened. This need can be solved by creating a news feature by providing up-todate information and knowledge around the campus. The risks in this feature are invalid information and knowledge about the campus.

3. Assumption \#4 get a value of 500

It is believed that students and students need a comment feature on the Event to interact with each other or question and answer in the event information that will be held. This need can be solved by creating a comment feature on the Event that all users can use. The risks in this feature are students and students commenting with poor language or speech.

4. Assumption \#5 get a value of 486

It is believed that students and students need a Bookmark feature to make it easier to save or speed up the search for information and group discussions. This need can be solved by creating a Bookmark feature that can be used to alert information and group discussions. The risk in this feature is that the user does not delete unused Bookmarks so that on the Bookmarks page.

5. Assumption \#2 get a value of 480

It is believed that students and students need group discussion for there to be direct interaction between users. This need can be solved by creating a group discussion feature where users can communicate with several other users at the same time. The risk in this feature is that users get spam or useless notifications.

These five assumptions are also made in the form of hypotheses to determine the purpose of each assumption for the user. Here's a hypothetical of each assumption:

1. Assumption \#3

It is believed that the knowledge sharing feature is right for users who want to share knowledge or knowledge about student activities. It is said to be true when this feature can help other users gain knowledge around student activities.

2. Assumption \#1

It is believed that the news feature is right for users in making it easier to get information about campuses that are happening or that have happened. It is said to be true when this feature can provide up-to-date information and knowledge to its users.

3. Assumption \#4

It is believed that the comment feature on the event is appropriate for users who want to comment on what has been disseminated. 
It is said to be true when this feature can provide interference, so many users are interested in reading the Event.

4. Assumption \#5

It is believed that the Bookmark feature is right for users who want to sign information and group discussions. It is said to be true when this feature can make it easier to save or speed up searching for information and group discussions.

5. Assumption \#2

It is believed that the group discussion feature is appropriate to have discussions with other users at the same time. It is said to be true when this feature can facilitate interacting and exchanging thoughts directly.

In the proto-persona image in Fig. 3., the user is an IT student of Telkom Purwokerto and is 22 years old. The user's need is to gain knowledge about the campus with a comfortable look. Therefore, the potential solution is to create a mobile version of the kms application with a simple interface android operating system that makes it easier to access it.

\begin{tabular}{|c|c|}
\hline $\begin{array}{c}\text { EZEKEL PRADIPTA NURSETYO } \\
\text { REGINANDA } \\
22 \text { year old } \\
\text { From Purwokerto, } \\
\text { Jawa Tengah, Indonesia }\end{array}$ & $\begin{array}{l}\text { - IT Telkom Purwokerto } \\
\text { students. } \\
\text { - Accustomed to using } \\
\text { a smartphone with the } \\
\text { Android operating } \\
\text { system }\end{array}$ \\
\hline $\begin{array}{l}\text { Needs } \\
\text { - Want to get knowledge } \\
\text { about campus easily. } \\
\text { - Want to get a comfortable } \\
\text { display when using the } \\
\text { KMS application with the } \\
\text { Android operating } \\
\text { system. }\end{array}$ & $\begin{array}{l}\text { Solution } \\
\text { - A mobile version of the } \\
\text { KMS application with } \\
\text { Android operation is } \\
\text { required. } \\
\text { - Simple interface that } \\
\text { makes access easier. }\end{array}$ \\
\hline
\end{tabular}

Fig. 3. Proto-persona IT Student Telkom Purwokerto

Lastly, on a collaborative design produced design studio and style guide. The result of the design studio is a rough sketch or wireframe depicting the initial design of the application display that can be seen in Fig. 4., the style guide for the primary color of the application in Fig. 5., the list of icons used in Fig. 6. and font type in Fig. 7.

In Fig. 4. design studio, made in the form of mockups using Balsamiq application. The features in the wireframe design are derived from assumptions that have previously been made. The colors for the app's appearance are also listed in Fig. 5.

In Fig. 6. using Google Material Design icon design. The Google Material Design icon was chosen because it has a complete icon design pattern and is familiar to users because it is used in every Google application. For comfort and consistency, in Fig. 7. Used fonts with Roboto type. 


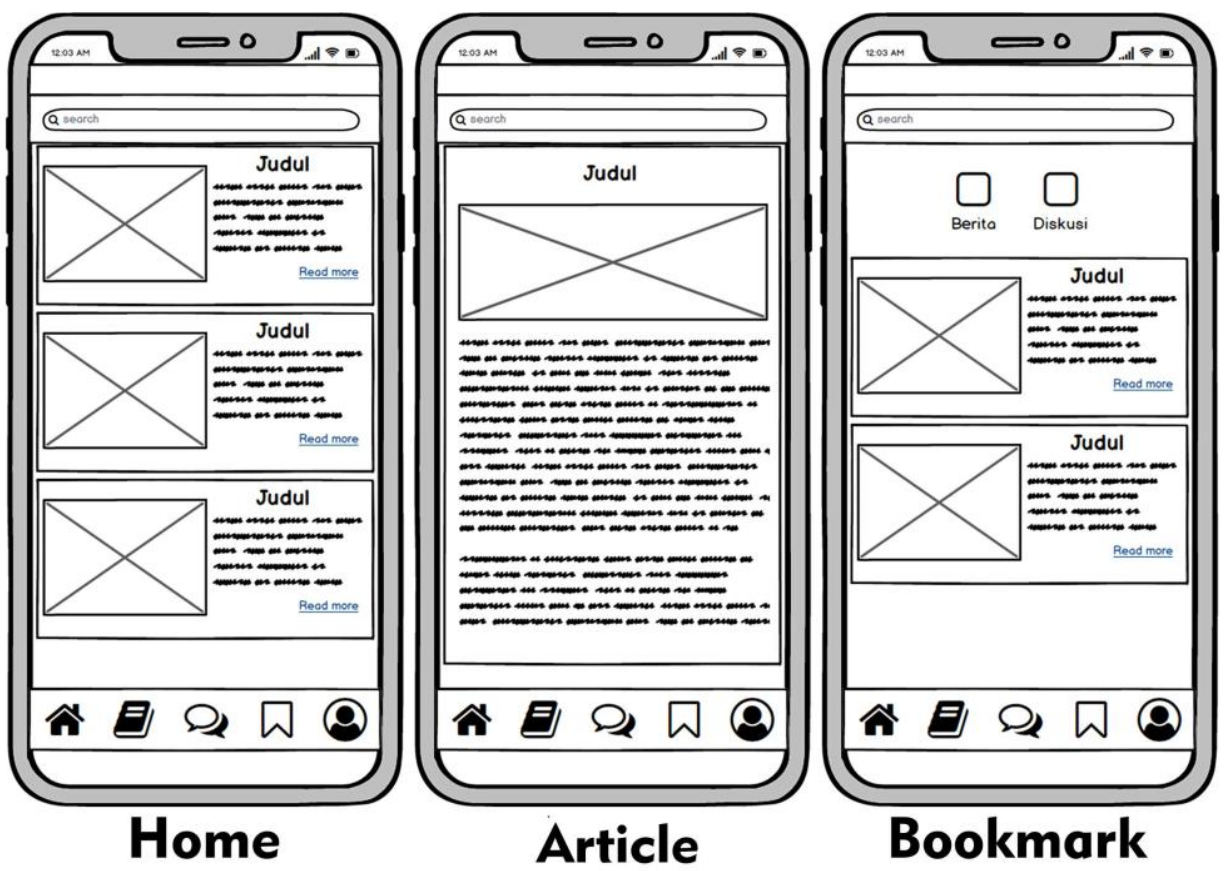

Fig. 4. KMS student wireframe

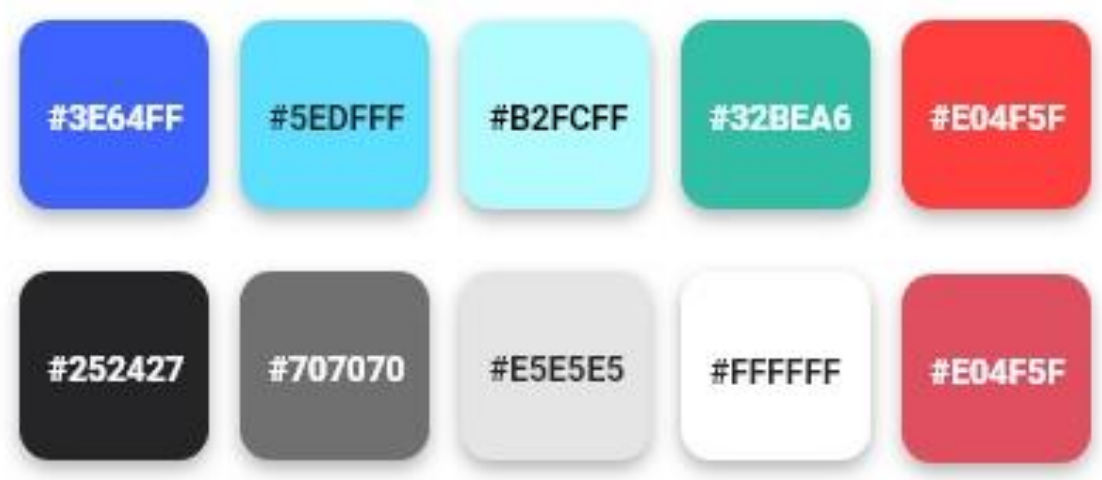

Fig. 5. Palette style guide

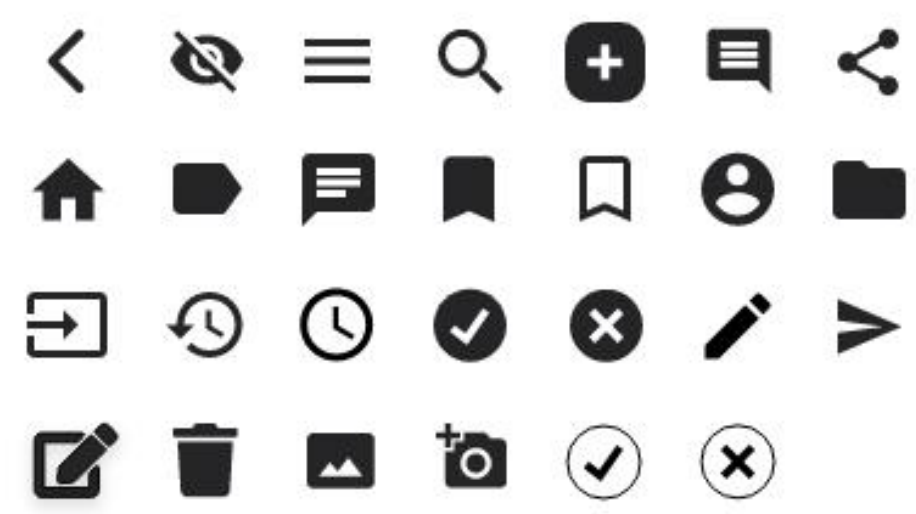

Fig. 6. style guide Icon Google Material Design 


\section{Roboto}

\section{A ABCDEFGHIJKLMNOPQRSTUVWXYZ \\ abcdefghijkImnopqrstuvwxyz \\ 1234567890 \\ (.,!@\#\$\%^\&*+=-_[ \{\}$\backslash::, \cdot, \cdot, / ?<>\sim ~)$
A ABCDEFGHIJKLMNOPQRSTUVWXYZ abcdefghijklmnopqrstuvwxyz 1234567890
(.,!@\#\$\%^\&*+=-_[D\}\::",.,/?<> )

Fig. 7. Style guide font

\subsection{Create an MVP}

The MVP-making stage is the implementation stage of the application design that generates prototypes. Prototype results for the homepage and article pages can be found in Fig. 8. and prototype results for navigation pages and search pages can be seen in Fig. 9.

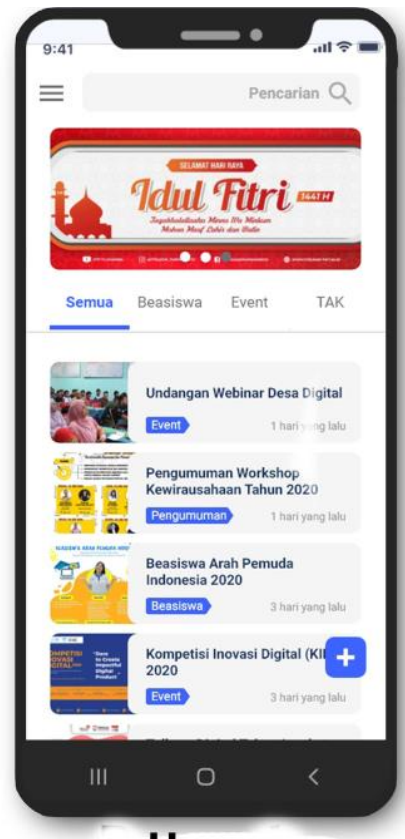

Home

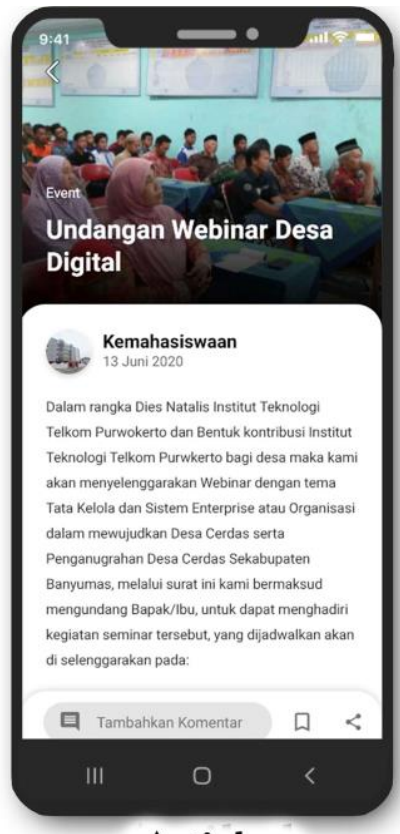

Article

Fig. 8. Home and article prototype results

Fig. 8. (Home) is the view on the home page. There are icons to go to the navigation page, search menu, a header containing images, navigation labels, news cards, and icons to go to the page create articles on the home page. If the user presses one of the news cards, the view will switch to the article page.

On the article page, as can be seen in Fig. 8. (Article), in the top left corner, there is an icon to return to the home page. The article page has images for articles, labels, titles, photos, the author of the article, the date the article was mentioned, and the article's content. There is also a share button, a bookmark, and a button to go to the comments page. 


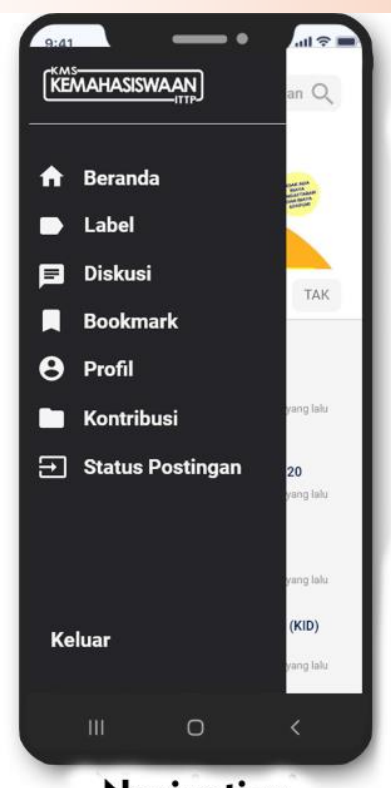

Navigation

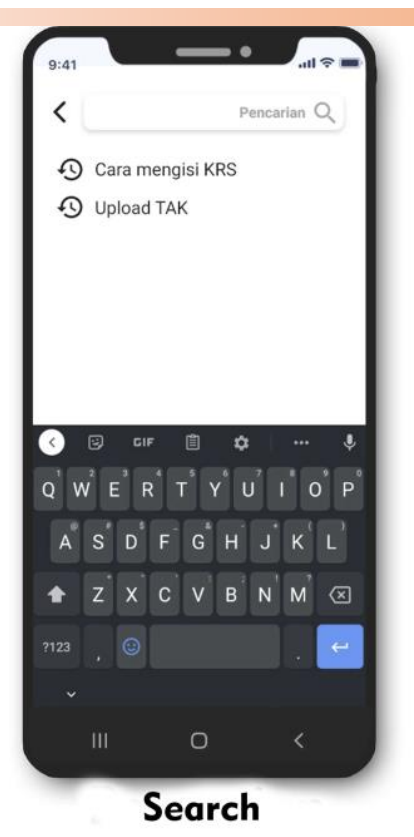

Search

Fig. 9. Navigation and search prototype results

Fig. 9. (Navigation) is a navigation page. The navigation page can be opened when the user presses the icon located in the top left corner. Navigation pages are used to make it easier for users when they want to move to another page. There are buttons to the page on the navigation page, sign in/sign up, homepage, labels, discussions, bookmarks, profile, contributions, post status, and exit. However, if the user enters as a student, then on the navigation page, there will be no menu to go to the status page of the post because the name is specifically created only for students when they want to approve an article that the student has created.

Fig. 9. (Search) is a search page. The search page can be accessed if the user presses the search menu on a page. There is a search menu, search history, an icon on the search page to go back to the previous page.

\subsection{Run an Experiment}

At this stage, the prototype is demonstrated and evaluated by the developer before being tested by a sample user. When conducting experiments, the designer evaluates the MVP results and then records each improvement made. The testing process is done by repeating several prototypes until it is believed that there are no errors. Evaluation results from developers are added to the list of fixes.

\subsection{Feedback and Research}

The final result of the prototype was tested using enhanced cognitive walkthrough evaluation. When evaluating, the tester also opens and practices a demo of the application view. This test aims to obtain feedback from the user and find out if the user understands each command on each task on each page of the prototype.

Each prototype page on the enhanced cognitive walkthrough evaluation is numbered, making it easier to research. The evaluation questionnaire was distributed to five students and one IT student of Telkom Purwokerto from February 15, 2021, to February 18, 2021. Based on the evaluation results that have been done using the enhanced cognitive walkthrough method, the prototype IT Telkom Purwokerto student knowledge management system has been following 
evaluators' expectations. This means the prototype of TELKOM Purwokerto's IT student knowledge management system has achieved a good user experience.

\section{Conclusion}

In this research, the prototype of knowledge management system or Knowledge Management System of IT student affairs Telkom Purwokerto. The design of the user interface and user experience is done using the Lean UX method. User samples play a big role in the design process so that the prototype results will match the user's goals. Prototype Knowledge Management System IT Telkom Purwokerto student affairs can be accessed in http://bit.ly/KMSkemahasiswaanbaru using a web browser application. Based on the evaluation results that have been done, the prototype IT Telkom Purwokerto student knowledge management system has achieved a good user experience.

\section{References}

[1] Kemahasiswaan, "Struktur Organisasi IT Telkom Purwokerto _ Official Blog Kemahasiswaan.”https://kemahasiswaan.ittelkom-pwt.ac.id/2018/05/19/struktur-organisasi/ (accessed Dec. 25, 2019).

[2] I. Nonaka, "Imported from Schein, E. H. (2010). Organizational culture and leadership (Vol. 2). John Wiley \& Sons," vol. 5, no. 1, 1994

[3] J. H. Saragih and T. D. Valentina, "Hubungan antara kecerdasan emosional dengan prestasi akademik pada mahasiswa aktivis organisasi kemahasiswaan di lingkungan Unversitas Udayana," J. Psikol. Udayana, vol. 2, no. 2, pp. 246-255, 2015.

[4] R. B. Permana, "Pengembangan front-end knowledge management system (kms) pada aplikasi mobile digital tani dengan menggunakan rest api reza bagus permana," Bogor Agric. Univ., 2018.

[5] StatCounter GlobalStats, "Mobile Operating System Market Share Europa | StatCounter Global Stats," Statcounter, 2019.

https://gs.statcounter.com/osmarketshare/mobile/worldwide\%0Ahttp://gs.statcounter.com/o s-market-share/mobile/ecuador (accessed Jan. 12, 2021).

[6] A. C. Wardhana, Y. Nurhadryani, S. Wahjuni, D. I. Komputer, F. Informatika, and P. Korespondensi, "Knowledge Management System Berbasis Web Tentang Budidaya WebBased Knowledge Management System Concerning Hydroponic Cultivation To Support Smart Society," J. Teknol. Inf. dan Ilmu Komput., vol. 7, no. 3, 2020, doi: 10.25126/jtiik.202072200.

[7] D. A. Ramadhan and J. A. P. Gultom, "Perancangan Web Pelayanan Perizinan Pemerintah Menggunakan Lean UX," J. Ilmu Komput. dan Agri-Informatika, vol. 7, no. 1, pp. 21-30, 2020, doi: 10.29244/jika.7.1.21-30.

[8] J. Gothelf, L. A. Liikkanen, H. Kilpiö, L. Svan, and M. Hiltunen, Lean UX. California: O'reilly, 2014.

[9] J. J. Garrett, The Elements of User. California, 2011.

[10] “Tentang Kami- Institut Teknologi Telkom Purwokerto." https://ittelkom-pwt.ac.id/. (accessed Jan. 18, 2021). 